\title{
Assessment of udder health in lame cows
}

\author{
Vladimír Hisira, Pavel Slovák, Paulína Marčeková, Marián Kadaši, Pavol Mudroň \\ University of Veterinary Medicine and Pharmacy, Clinic of Ruminants, Košice, Slovakia
}

Received April 8, 2017

Accepted April 30, 2020

\begin{abstract}
The objective of this study was to assess the udder health in lame dairy cows. The study was performed on 35 dairy cows which were admitted to the Clinic of Ruminants. The most frequent claw diseases were white line abscess $(28.6 \%)$ and toe necrosis $(28.6 \%)$, followed by digital dermatitis $(17.1 \%)$, toe ulcers $(14.3 \%)$, and sole ulcers $(11.4 \%)$. The prevalence of mastitis in lame cows was $74.3 \%$ (26); clinical mastitis was detected in $5(19.2 \%)$ and subclinical mastitis in $21(80.8 \%)$ dairy cows. Distribution of mastitis was similar in terms of front $(52.54 \%)$ and rear quarters $(47.46 \%)$. For statistical analyses of mastitis grade in lame dairy cows, a six-point Mastitis Score was created based on physical examination of the mammary gland and results of California Mastitis Test. The Mastitis Score tended to be higher in cows with corium inflammation than in those with digital dermatitis (10.0 and 6.5, respectively). Microbiological culture of 24 positive milk samples was performed and intra-mammary pathogens were isolated in $18(75 \%)$ samples. The most prevalent bacteria were coagulase negative staphylococci $(50 \%)$, followed by Enterococcus spp. (16.7\%), Proteus spp. (11.1\%), and Aerococcus viridians $(11.1 \%)$. Of the total bacteria, contagious pathogens were determined in two milk samples $(11.1 \%)$. In conclusion, high prevalence of mastitis was detected in lame cows suffering from claw diseases without a significant effect of the type of claw diseases on the mastitis grade. Moreover, the dominating isolation of environmental pathogens may be a result of longer lying period of animals affected with lameness.
\end{abstract}

Mastitis, lameness, claw disease, dairy cattle

Bovine mastitis is a large-scale infectious disease with significant impact on the economy of milk production and causes significant direct and indirect economic losses in dairy industry world-wide (Halasa et al. 2007; Awale et al. 2012). Mastitis-related financial losses are associated with reduction in milk yield, increased treatment costs, higher discarded milk, increase in culling and replacement rates, impaired reproductive performance and financial penalties for exceeding legal milk quality limits (Hortet and Seegers 1998; Kocak and Ekiz 2006; Gunay and Gunay 2008). The incidence of mastitis in dairy herds results from a complex interaction between the infectious agents, poor management practices, genetic and environmental factors, stressing the defence of the udder (Nakov et al. 2014). It is well known that many factors may change the susceptibility to mastitis, negatively influencing the cow's local and systemic barriers and defence, or increasing the exposure of the udder to micro-organisms (Burvenich et al. 2003; Nyman et al. 2007). The most common potential risk factors for mastitis on dairy farms are classified as quarter, cow and environmental risk factors (Nayan et al. 2014). A great number of quarter risk factors for mastitis have been described, including previous bacterial infection, immunity of the udder (Sordillo et al. 1997), injury to the udder and teat, pendulous udder, defect of the teat sphincter (trauma previous to infection, quarters with hyperkeratosis, udder quarters position, udder shape, teat shape, size, and position udder (Breen et al. 2009, Zadoks et al. 2001). Cow-level risk factors reported for mastitis include the age (Steeneveld et al. 2008), breed (Elbers et al. 1998), genetic factors, parity, stage of lactation, lactation number (Zadoks et al. 2001), milk yield, leaking milk (O'Reilly et al. 2006), checking

Address for correspondence:

MVDr. Vladimir Hisira, PhD.

Clinic of Ruminants

University of Veterinary Medicine and Pharmacy

Komenského 73, 04181 Košice, Slovak Republic

Phone: +421905833192

E-mail: vladimir.hisira@uvlf.sk

http://actavet.vfu.cz/ 
foremilk before attaching the clusters, immune status, physical conditions, hygiene of cows/cow cleanliness (Ward et al. 2002), peripartal diseases and lameness (Peeler et al. 1994; Sato et al. 2008). In the current literature, many environmental risk factors for mastitis are identified by researchers. The environmental risk factors include nutrition (Perkins et al. 2001), feeding, housing system, type of bedding (Peeler et al. 2000), herd size, pasture condition, season, climate, poor management practices, sanitary conditions and milking methods/milking hygiene (Nyman et al. 2007; Valde et al. 2007). It has been hypothesized that lameness with a longer lying time increases the risk of bacterial contamination of the teat canals and that cows that lie down immediately after milking would be at most risk of acquiring intra-mammary pathogens. Therefore, lameness may be viewed as one of the most risk factors responsible for distribution of mastitis in herds with increased prevalence of lameness. The relationship between lameness was studied by several authors, who confirmed the effect of poor hoof health and decreased milk yield, affected milk composition and prevalence of mastitis (Arvidson 2000; Olechnowicz and Jankowski 2012; Singh et al. 2018)

The objective of this study was to assess the udder health of lame dairy cows admitted to the Clinic of Ruminants of the University of Veterinary Medicine and Pharmacy in Kosice.

\section{Animals}

\section{Materials and Methods}

The study was conducted on all Holstein-Friesian dairy cows $(n=35)$ with locomotor disorders, hospitalized at the Clinic of Ruminants of the University of Veterinary Medicine and Pharmacy in Kosice, Slovak Republic, between 2011 and 2014. The cows were referred from four dairy farms in Eastern Slovakia.

\section{Orthopaedic examination}

Each animal was examined in the trimming crush for causes of the lameness. Based on the clinical findings, a diagnosis of the limb health disorder was made using the updated orthopaedic terminology for cattle (EggerDanner et al. 2015). Subsequently, the lesions were treated and all the data were recorded for statistical analysis.

\section{Examination of mammary gland}

Clinical examination of the udder was performed by visual inspection and palpation, using standard physical methods of examination. The initial milk stripped from each teat was discarded and individual milk samples from lactating cows were physically examined (Rosenberger et al. 1979). Clinical mastitis was diagnosed by the presence of observable signs of inflammation in the affected quarter such as swelling, heat, pain or redness and by presence of macroscopically altered milk in one or more quarters.

To detect subclinical mastitis, California mastitis test (CMT) was performed on each milk sample free of visible abnormalities. The CMT results were interpreted according to the CMT scoring system: negative, trace, 1, 2, and 3 (Jackson and Cockcroft 2002).

\section{Bacteriological examinations}

Microbiological culture was performed with 24 milk samples which were positive either by clinical or by CMT examination. Briefly, milk samples $(10 \mu \mathrm{l})$ were incubated at $37{ }^{\circ} \mathrm{C}$ using Columbia blood agar base with $5 \%$ of defibrinated blood, Staphylococcal medium $N^{\circ} 110$, Baird-Parker agar, Edwards Medium, Mac Conkey Agar (Oxoid, (OXOID Ltd., Basingstoke, Hants, UK) for 18-24 h. The following assays were used to determine bacterial species: pigment and coagulase production, catalase activity, haemolysis, Gram staining, and other virulence factors. Commercial kits STAPHYtest 24; STREPTOtest 24, resp. ENTEROtest 24 (Erba Lachema, Brno, ČR) were used to identify the bacterial strains. All kits were evaluated by the programme TNW ProAuto 7.0 ${ }^{\circledR}$ (Erba Lachema,

Table 1. Mastitis Score (MS).

\begin{tabular}{lll}
\hline Score & Description & California Mastitis Test \\
\hline 1 & Healthy milk & Negative \\
2 & Doubtful mastitis of one quarter & Trace: $200,000-400,000$ \\
3 & Weak Subclinical mastitis & $1: 400,000-1,200,000$ \\
4 & Distinct Subclinical mastitis & $2: 1,200,000-5,000,000$ \\
5 & Strong Subclinical mastitis & $3:$ over $5,000,000$ \\
6 & Clinical mastitis & \\
\hline
\end{tabular}

Brno, Czech Republic) according to the manufacturer's instructions. Coagulasenegative staphylococci (CNS) were identified by typical colony morphology and negative coagulase reaction.

\section{Statistical analysis}

For statistical analyses of mastitis grade in lame dairy cows a six-point Mastitis Score (MS) was created based on physical examination of the mammary gland and CMT (Table 1). 
The final value of MS is a sum of points given to each udder quarter. Thus, the minimal MS is 4 and maximal 24 points. The animals were divided according the orthopaedic diagnosis into two groups: corium inflammation (toe ulcer, sole ulcer, toe necrosis, white line abscess) and digital dermatitis. The significance of differences in MS between the groups was tested by Student's $t$-test. The level of significance was set at $P<0.05$.

\section{Results}

Lameness in studied dairy cows was caused by toe necrosis (10 cows, $28.6 \%$ ), white line abscess (10 cows, $28.6 \%$ ), digital dermatitis (6 cows, 17.1\%), toe ulcer ( 5 cows, $14.3 \%$ ), and sole ulcer (4 cows, $11.4 \%$; Table 2; Fig. 1). The corium inflammation and digital dermatitis groups consisted of $29(83 \%)$ and six animals (17\%), respectively. Claw diseases affected rear limbs in 31 cows $(86 \%)$ and only in four cows $(14 \%)$ the front limbs were affected. Mastitis was found in 26 dairy cows (74.3\%); the subclinical and clinical form of mammary gland inflammation was found in 21 and 5 animals, respectively (Table 2). Distribution of mastitis was similar between front $(52.5 \%)$ and rear quarters $(47.5 \%)$. There were no differences $(P=0.17)$ between the mastitis rate in cows with corium inflammation and digital dermatitis $(69 \%$ and $67 \%$, respectively). The statistical analysis of MS did not reveal any significant difference between cows with different types of claw inflammation (Table 3).

Table 2. Prevalence of mastitis in lame dairy cows hospitalized at the Clinic of Ruminants of the University of Veterinary Medicine and Pharmacy.

\begin{tabular}{lcccc}
\hline & Number of dairy cows & Mastitis & Clinical mastitis & Subclinical mastitis \\
\hline Toe necrosis & 10 & $7(70 \%)$ & 2 & 5 \\
White line abscess & 10 & $7(70 \%)$ & 3 & 4 \\
Digital dermatitis & 6 & $4(66.7 \%)$ & 0 & 4 \\
Toe ulcer & 5 & $5(100 \%)$ & 0 & 5 \\
Sole ulcer & 4 & $3(75 \%)$ & 0 & 3 \\
Total & 35 & $26(74.3 \%)$ & 5 & 21 \\
\hline
\end{tabular}

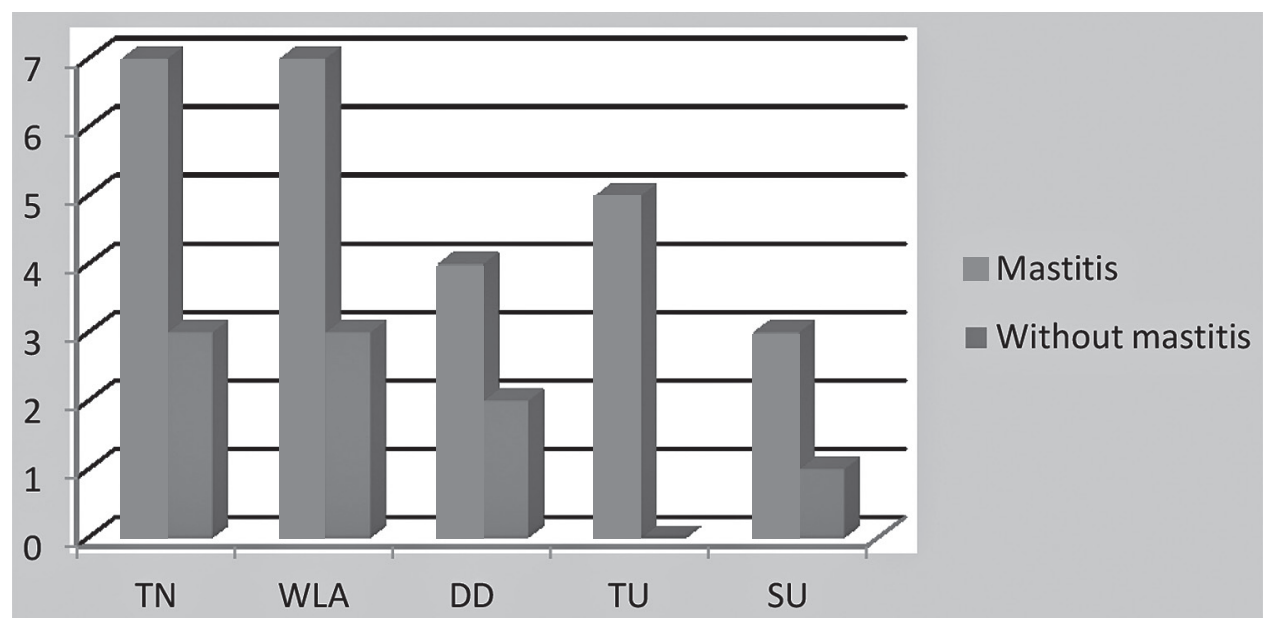

$\mathrm{TN}$ - toe necrosis, WLA - white line abscess, DD - digital dermatitis, TU - toe ulcer, SU - sole ulcer

Fig. 1. Distribution of mastitis in lame cows affected by certain claw diseases. 
Table 3. Mastitis score in lame dairy cows.

\begin{tabular}{lcc}
\hline & $\begin{array}{c}\text { Number of } \\
\text { dairy cows }\end{array}$ & $\begin{array}{c}\text { Mastitis score } \\
(\mathrm{x} \pm \mathrm{SD})\end{array}$ \\
\hline Corium inflammation & 29 & $10.0 \pm 5.83$ \\
Digital dermatitis & 6 & $6.50 \pm 2.59$ \\
\hline
\end{tabular}

$\mathrm{x}$ - mean; SD - standard deviation
Microbiological culture was performed in 24 samples randomly selected from all positive milk samples $(n=40)$ to determine the distribution of intra-mammary pathogens in lame cows. Intra-mammary pathogens were isolated in

$18(75 \%)$ samples. There was no growth in 6 milk samples $(25 \%)$. The most prevalent bacteria were coagulase-negative staphylococci (50\%), followed by Enterococcus spp. (16.7\%), Proteus spp. (11.1\%), and Aerococcus viridians (11.1\%). Of the total bacteria contagious pathogens were determined in two milk samples (11.1\%, Table 4).

Table 4. Bacterial isolation from the milk samples $(n=24)$ of cows with claw diseases.

\begin{tabular}{lll}
\hline Positive & & $18(75 \%)$ \\
\hline Contagious pathogens & & $2(11.1 \%)$ \\
\hline Environmental pathogens & Streptococcus agalactiae & $2(11.1 \%)$ \\
\hline & Enterococcus spp. & $16(88.9 \%)$ \\
\hline & Aerococcus viridans & $2(16.7 \%) 1 / 3 \mathrm{WLA}, 1 / 3 \mathrm{TU}, 1 / 3 \mathrm{DD}$ \\
& Proteus spp. & $2(11.1 \%) 2 / 2 \mathrm{SU}$ \\
& CNS & $9(50 \%)$ \\
& Staphylococcus chromogenes & $21 / \mathrm{TN}, 1 / \mathrm{DD}$ \\
& Staphylococcus warneri & $54 / \mathrm{TN}, 1 / \mathrm{SU}$ \\
& Staphylococcus equorum & 2 D \\
& & $6(25 \%)$
\end{tabular}

DD - digital dermatitis; SU - sole ulcer; TN - toe necrosis; TU - toe ulcer; WLA - white line absces; CNS - coagulase-negative staphylococci

\section{Discussion}

Many risk factors play a role in the development of clinical and subclinical mastitis. Lameness should be included in them. The predominant causes of severe lameness in cows are claw diseases. Dairy Herd Improvement (DHI) numbers for the University of Florida Research herd in 1995 showed a $35 \%$ incidence of clinical lameness in cows. Claw problems (sole ulcers and white line disease) accounted for 63 percent of the reported cases. Digital dermatitis and foot rot accounted for 20 percent, and 17 percent of the cases, respectively (Stokka et al. 1996). Locomotion score has been used widely to investigate the degree of lameness. Increased locomotion score is associated with an increased percentage of cows lying down; also the cows' posture in the milking parlour is associated with lameness (Olechnowicz and Jaskowski 2012). Once lameness is developed, cows spend less time standing at the feeding troughs (González et al. 2008; Gomez and Cook 2010), and they can be observed to spend more time lying down compared to healthy cows (Chapinal et al. 2010) which consequently increases the risk of mastitis. It has long been known that the onset of intra-mammary infection is dependent on contamination and hygiene not only of the environment but also of the animals' surface area. An index of environmental sanitation based on the amount of manure present on the cow skin and in its environment was defined as a predictor for the occurrence of coliform mastitis (Bartlett et al. 1992). The lowest incidence of mastitis occurred in herds with the cleanest cows and the most satisfactory beds (Ward et al. 2002). The rate of new intra-mammary infection is just related to the number of bacteria that the teat end is exposed to (Neave et al. 1966). 
A study was carried out across U.S. dairy farms to detect the association between the hygiene score of the udder and legs with the occurrence of mastitis; it found a significantly higher prevalence of intra-mammary pathogens with a higher hygiene score of the udder (Schreiner and Ruegg 2003). Poorly trimmed hooves and lameness were connected with impaired lying-down and rising behaviour; this acts as a risk factor for teat tramps (Rajala-Schultz and Gröhn 1999) which in turn predicts clinical mastitis. The longest duration of lying time was observed in lame cows suffering from claw lesions affecting the sole or the junction between the sole and the wall of the claw. More time spent by lying down was associated with extreme exposition of the udder to environmental pathogens and influenced the manifestation of mastitis (Singh et al. 1993). Our results confirmed this hypothesis, whereby the most prevalent intra-mammary pathogens in positive milk were environmental bacteria (coagulase-negative staphylococci, Enterococcus spp., Proteus spp., and Aerococcus viridians). Poor dairy cow hygiene is consistently related to the increase of the somatic cell count (SCC) in milk. In a Canadian study, investigators discovered that SCC in milk increased with increasingly dirty stalls (DeVries et al. 2011).

It has been hypothesized that lameness together with subsequent prolonged lying time increases the risk of bacterial contamination of the teat canals and cows that lie down immediately after milking would be at a higher risk of suffering from intra-mammary infection. Therefore, lameness may be viewed as one of the most common risk factors responsible for the distribution of mastitis in dairy herds with increased prevalence of lameness. In line with previous works (Peeler et al. 1994; Sato et al. 2008) our study noted an association between lameness and mastitis, where the prevalence of mastitis was very high in cows that suffered from claw diseases $(74.3 \%)$. Similarly, a negative effect of lameness on mastitis in dairy herds was previously demonstrated in a study of ten dairy herds in the southwest of England. Clinical lameness before the first service was associated with a 1.4-fold increase in the odds of clinical mastitis (Peeler et al. 1994). According to a Danish study, claw diseases were significantly associated with the mastitis incidence rate (Sato et al. 2008). In a Swedish observational study, a close relationship was documented between poor foot health and a high incidence of clinical mastitis (Arvidson 2000). Moreover, other research reported the prevalence of the sole ulcer to be related to udder disorders (Vaarst et al. 1998). A negative association between hoof trimming and mastitis at the herd level was also found in an earlier study (Østerås and Lund 1988). Recently, a significant difference in the mastitis rate between healthy and lame cows was reported (Mudron 2016).

In contrast, in a study from Bulgaria no association between lameness and subclinical mastitis was determined, where the prevalence of mastitis in lame cows was only $5.5 \%$ (Mitev et al. 2011). No significant differences in SCC between clinically lame cows and healthy cows were determined on Polish Holstein Friesian dairy farms (Olechnowicz and Jankowski 2012). No relationship between lameness and mastitis was confirmed in a study carried out on 102 Swedish dairy herds by Hultgren et al. (2004); in accordance with this observation, statistical analysis showed only a strong relationship between teat injuries and mastitis. However, no associations were proved between the sole ulcer and clinical mastitis or high milk cell counts. This might be explained as a result of relatively mild lameness of the affected cows. Possibly, only severe lameness impairs the cow's locomotion and increases the risk of teat injuries and subsequent mastitis. The analyses indicated that teat injury was neither an intervening variable between the sole ulcer and mastitis or high cell counts, nor a confounder.

The incidence of mastitis in cattle herds is influenced by the hygiene of the udder and the environment. Similarly, the overall time spent by lying down plays an important role in the distribution of mastitis. Another study found no relationship between mastitis and lameness, and a relatively low prevalence of mastitis was observed in lame cows (Heuer 
et al. 1999). In a study from the UK, a relationship among the occurrence of lameness, the locomotion score and SCC was analysed in 1,397 cows on seven dairy farms. In cows with a higher locomotion score, lower SCC was detected compared to the cows with a lower locomotion score (Archer et al. 2011).

Moreover, similar distribution of mastitis among different quarters was observed in our research. The ratio between front and rear quarters was 53:47 and no significant difference was observed in the incidence among quarters. In line with our results, no significant difference in the prevalence of mastitis between different quarters was confirmed in a study by Hashemi et al. (2011). However, several observations noted a significantly higher prevalence of intra-mammary infections (IMI) in rear quarters in cows suffering from particularly clinically manifested mastitis (Barkema et al. 1997; Berry and Meaney 2006; Maćešić et al. 2012). This variation could have resulted from udder morphology and higher milk production of rear quarters (Lancelot et al. 1997). In spite of previous research, the prevalence of mastitis could have resulted from generalized cow differences, such as individual milk yield, immune competency, mammary type characteristics, and general health state (Adkinson et al. 1993).

In conclusion, our analysis confirmed a strong association between lameness and mastitis. Lameness may be characterised as one of the risk factors contributing to the increased prevalence of mastitis in dairy herds. However, no significant differences were observed in severity of mastitis in dairy cows with different type of claw diseases.

\section{Acknowledgement}

This work was supported by Research Grant Agency of the Ministry of Education, Science, Research and Sport of the Slovak Republic (VEGA 1/0107/17).

\section{References}

Adkinson RW, Ingawa KH, Blouin DC, Nickerson SC 1993: Distribution of clinical mastitis among quarters of the bovine udder. J Dairy Sci 76: 3453-3459

Archer SC, Green MJ, Madouasse A, Huxley JN 2011: Association between somatic cell count and serial locomotion score assessments in UK dairy cows. J Dairy Sci 94: 4383-4388

Arvidson AK 2000: Environmental and management factors associated with the incidence of clinical mastitis in high yielding dairy herds with a low incidence of subclinical mastitis. Graduate Report 136. Department of Animal Nutrition and Management, Swedish University of Agricultural Science, Uppsala, Sweden, 72 p.

Awale MM, Dudhatra GB, Avinash K, Chauhan BN, Kamani DR, Modi CM, Patel HB, O'Kennedy R 2012: Bovine mastitis: a threat to economy. Open Access Scientific Reports 1: 295

Barkema HW, Schukken YH, Lam TJ, Galligan DT, Beiboer ML, Brand A 1997: Estimation of interdependence among quarters of the bovine udder with subclinical mastitis and implications for analysis. J Dairy Sci 80: 1592-1599

Bartlett PC, Miller GY, Lanc SE, Heider LE 1992: Managerial determinants of intramammary coliform and environmental Streptococci infections in Ohio dairy herds. J Dairy Sci 75: 1241-1252.

Berry DP, Meaney WJ 2006: Interdependence and distribution of subclinical mastitis and intramammary infection among udder quarters in dairy cattle. Prev Vet Med 75: 81-91

Breen JE, Green MJ, Bradley AJ 2009: Quarter and cow risk factors associated with the occurrence of clinical mastitis in dairy cows in the United Kingdom. J Dairy Sci 92: 2551-2561

Burvenich C, Van Merris V, Mehrzad J, Diez-Fraile A, Duchateau L 2003: Severity of E. coli mastitis is mainly determined by cow factors. Vet Res 34: 521-564

Chapinal N, de Passillé AM, Rushen J, Wagner S 2010: Automated methods for detecting lameness and measuring analgesia in dairy cattle. J Dairy Sci 93: 2007-2013

DeVries TJ, Deming JA, Rodenburg J, Seguin G, Leslie KE, Barkema HW 2011: Association of standing and lying behaviour patterns and incidence of intramammary infection in dairy cows milked with an automatic milking system. J Dairy Sci 94: 3845-3855

Egger-Danner C, Nielsen P, Fiedler A, Müller K, Fjeldaas T, Döpfer D, Daniel V, Bergsten C, Cramer G, Christen AM, Stock KF, Thomas G, Holzhauer M, Steiner A, Clarke J, Capion N, Charfeddine N, Pryce E, Oakes E, Burgstaller J, Heringstad B, Ødegård C, Kofler J 2015: ICAR Claw Health Atlas. Rome, ICAR, 45 p., http://www.icar.org/Documents/ ICAR Claw Health Atlas.pdf.

Elbers AR, Miltenburg JD, De Lange D, Crauwels AP, Barkema HW, Schukken YH 1998: Risk factors for clinical mastitis in a random sample of dairy herds from the southern part of the Netherlands. J Dairy Sci 81: 420-426 
Gomez A, Cook NB 2010: Time budgets of lactating dairy cattle in commercial freestall herds. J Dairy Sci 93: 5772-5781

González LA, Tolkamp BJ, Coffey MP, Ferret A, Kyriazakis I 2008: Changes in feeding behavior as possible indicators for the automatic monitoring of health disorders in dairy cows. J Dairy Sci 91: 1017-1028

Gunay A, Gunay U 2008: Effects of clinical mastitis on reproductive performance in Holstein cows. Acta Vet Brno 77: 555-560

Halasa T, Huijps K, Osteras O, Hogeveen H 2007: Economic effects of bovine mastitis and mastitis management: A review. Vet Quart 29: 18-31

Hashemi M, Kafi M, Safdarian M 2011: The prevalence of clinical and subclinical mastitis in dairy cows in the central region of Fars province, south of Iran. Iran J Vet Res 12: 236-241

Heuer C, Schukken YH, Dobbelaar P 1999: Postpartum body condition score and results from the first test day milk as predictors of disease, fertility, yield, and culling in commercial dairy herds. J Dairy Sci 82: 295-304

Hortet P, Seegers H 1998: Calculated milk production losses associated with elevated somatic counts in dairy cows: review and critical discussion. Vet Res 29: 497-510

Hultgren J, Manske T, Bergsten C 2004: Associations of sole ulcer at claw trimming with reproductive performance, udder health, milk yield, and culling in Swedish dairy cattle. Prev Vet Med 62: 233-251

Jackson P, Cockcroft P 2002: Clinical examination of farm animals. Blackwell Science Ltd., Oxford, UK: 154-166

Kocak Ö, Ekiz B 2006: The effect of lameness on milk yield in dairy cows. Acta Vet Brno 75: 79-84

Lancelot F, Faye B, Lescourret F 1997: Factors affecting the distribution of clinical mastitis among udder quarters in French dairy cows. Vet Res 28: 45-53

Maćešić N, Karadjole T, Bačić G, Benić M, Karadjole M, Vince S, Lipar M, Cergolj M 2012: Aetiology and prevention of bovine intrammamary infection at drying off. Vet Arh 82: 125-131

Mitev J, Gergovska Z, Miteva T, Penev T 2011: Influence of lameness on daily milk yield, lactation curve and body conditions score during lactation in black and white cows. Bulg J Agric Sci 17: 704-711

Mudron P 2016: Der Einfluss von Klauenerkrankungen auf Euterentzündungen und Fruchtbarkeitsparameter bei Milchkühen. Klauentierpraxis 24: 13-17

Nakov D, Hristov S, Andonov S, Trajchev N 2014: Udder-related risk factors for clinical mastitis in dairy cows. Vet Arh 84: 111-127

Nayan V, Bhardwaj A, Balhara A 2014: Mastitis in buffalo: Risk factors. (Online: http://www.buffalopedia.cirb. res.in/2014, accessed on $4^{\text {th }}$ April 2014)

Neave FK, Dodd FH, Kingwill RG 1966: A method on controlling udder disease. Vet Rec 78: 521-725

Nyman AK, Ekman T, Emanuelson U, Gustafsson AH, Holtenius K, Persson Waller K, Hallen Sandgren C 2007: Risk factors associated with the incidence of veterinary-treated clinical mastitis in Swedish dairy herds with a high milk yield and a low prevalence of subclinical mastitis. Prev Vet Med 78: 142-160

Olechnowicz J, Jaśkowski JM 2012: Relationship between clinical lameness and somatic cell counts, and fat and protein contents in the milk of dairy cows. Med Weter 68: 740-743

O’Reilly KM, Green MJ, Peeler EJ, Fitzpatrick JL, Green LE 2006: Investigation of risk factors for clinical mastitis in British dairy herds with bulk milk somatic cell counts less than 150,000 cells/mL. Vet Rec 158: 649-653

Østerås O, Lund A 1988: Epidemiological analyses of the associations between bovine udder health and housing. Prev Vet Med 6: 79-90

Peeler EJ, Green MJ, Fitzpatrick JL, Morgan KL, Green LE 2000: Risk factors associated with clinical mastitis in low somatic cell count British dairy herds. J Dairy Sci 83: 2464-2472

Peeler EJ, Otte MJ, Esslemont RJ 1994: Inter-relationships of periparturient diseases in dairy cows. Vet Rec 134: 129-132

Perkins KH, Vande Haar MJ, Tempelman RJ, Burton JL 2001: Negative energy balance does not decrease expression of leukocyte adhesion or antigen-presenting molecules in cattle. J Dairy Sci 84: 421-428

Rajala-Schultz PJ, Gröhn YT 1999: Culling of dairy cows. Part I. Effects of diseases on culling in Finnish Ayrshire cows. Prev Vet Med 41: 195-208

Rosenberger G, Dirksen G, Gründer HD, Grunert E, Krause D, Stöber M 1979: Clinical Examination of Cattle. Parey Press, Berlin, pp. 357-358

Sato K, Bartlett PC, Alban L, Agger JF, Houe H 2008: Managerial and environmental determinants of clinical mastitis in Danish dairy herds. Acta Vet Scand 50: 1-8

Schreiner DA, Ruegg PL 2003: Relationship between Udder and Leg Hygiene Scores and Subclinical mastitis. J Dairy Sci 86: 3460-3465

Singh SS, Ward WR, Lautenbach K, Murray RD 1993: Behaviour of lame and normal dairy cows in cubicles and in a straw yard. Vet Rec 133: 204-208

Singh A, Singh S, Gupta D K, Bansal B K 2018: Relationship of lameness to body condition score, udder health and milk quality in crossbred dairy cattle. Vet Arhiv 88: 179-190

Sordillo LM, Shafer-Weaver K, DeRosa D 1997: Immunobiology of the mammary gland. J Dairy Sci 80: 1851-1865

Steeneveld W, Hogeveen H, Barkema HW, van den Broek J, Huirne RBM 2008: The influence of cow factors on the incidence of clinical mastitis in dairy cows. J Dairy Sci 91: 1391-1402 
Stokka GL, Smith JF, Dunham JR, Van Anne T 1996: Lameness in dairy cattle. In: Dairy day 1996 Report of Progress 771 Agricultural Experiment Station. Kansas State University, Manhattan, pp. 46-50

Vaarst M, Hindhede J, Enevoldsen C 1998: Sole disorders in conventionally managed and organic dairy herds using different housing systems. J Dairy Res 65: 175-186

Valde JP, Lystad ML, Simensen E, Østerås O 2007: Comparison of feeding management and body condition of dairy cows in herds with low and high mastitis rates. J Dairy Sci 90: 4317-4324

Ward WR, Hughes JW, Faull WB, Cripps PJ, Sutherland JP, Sutherst JE 2002: Observational study of temperature, moisture, $\mathrm{pH}$ and bacteria in straw bedding, and faecal consistency, cleanliness and mastitis in cows in four dairy herds. Vet Rec 151: 99-206

Zadoks RN, Allore HG, Barkema HW, Sampimon OC, Wellenberg GJ, Gröhn YT, Schukken YH 2001: Cowand quarter-level risk factors for Streptococcus uberis and Staphylococcus aureus mastitis. J Dairy Sci 84: 2649-2663 